Baliatsas, C., Kamp, I. van, Hooiveld, M., Yzermans, J., Lebret, E. Comparing non-specific physical symptoms in environmentally sensitive patients: prevalence, duration, functional

\begin{tabular}{|c|c|}
\hline $\begin{array}{l}\text { Postprint } \\
\text { Version }\end{array}$ & 1.0 \\
\hline Journal website & http://www.sciencedirect.com/science/article/pii/S0022399914000506 \\
\hline Pubmed link & http://www.ncbi.nlm.nih.gov/pubmed/24745783 \\
\hline DOI & 10.1016/j.jpsychores.2014.02.008 \\
\hline
\end{tabular}

This is a NIVEL certified Post Print, more info at http:l/www.nivel.eu

\title{
Comparing non-specific physical symptoms in environmentally sensitive patients: Prevalence, duration, functional status and illness behavior
}

\author{
CHRISTOS BALIATSAS $^{\mathrm{A}, \mathrm{B},}$, IRENE VAN KAMP ${ }^{\mathrm{B}}$, MARIETTE HOOIVELD ${ }^{\mathrm{C}}$, JORIS YZERMANS ${ }^{\mathrm{C}}$, \\ ERIK LEBRET ${ }^{\mathrm{A}, \mathrm{B}}$ \\ ${ }^{a}$ Institute for Risk Assessment Sciences (IRAS), Utrecht University, Utrecht, The \\ Netherlands \\ ${ }^{\mathrm{b}}$ National Institute for Public Health and the Environment (RIVM), Bilthoven, The \\ Netherlands \\ ${ }^{c}$ Netherlands Institute for Health Services Research (NIVEL), Utrecht, The Netherlands
}

\begin{abstract}
Objective: Little is known about the potential clinical relevance of non-specific physical symptoms (NSPS) reported by patients with self-reported environmental sensitivities. This study aimed to assess NSPS in people with general environmental sensitivity (GES) and idiopathic environmental intolerance attributed to electromagnetic fields (IEI-EMF) and to determine differences in functional status and illness behavior.

Methods: An epidemiological study was conducted in the Netherlands, combining self-administered questionnaires with the electronic medical records of the respondents as registered by general practitioners. Analyses included $n=$ 5789 registered adult ( $\geq 18$ years) patients, comprising 5073 non-sensitive (NS) individuals, 514 in the GES group and 202 in the IEI-EMF group.

Results: Participants with GES were about twice as likely to consult alternative therapy compared to non-sensitive individuals; those with IEI-EMF were more than three times as likely. Moreover, there was a higher prevalence of symptoms and medication prescriptions and longer symptom duration among people with sensitivities. Increasing number and duration of self-reported NSPS were associated with functional impairment, illness behavior, negative symptom perceptions and prevalence of GP-registered NSPS in the examined groups.

Conclusion: Even after adjustment for medical and psychiatric morbidity, environmentally sensitive individuals experience poorer health, increased illness behavior and more severe NSPS. The number and duration of self-reported NSPS are important components of symptom severity and are associated with characteristics similar to those of NSPS in primary care.
\end{abstract}


Baliatsas, C., Kamp, I. van, Hooiveld, M., Yzermans, J., Lebret, E. Comparing non-specific physical symptoms in environmentally sensitive patients: prevalence, duration, functional status and illness behavior. Journal of Psychosomatic Research: 2014, 76(5), 405-413

The substantial overlap between the sensitive groups strengthens the notion that different types of sensitivities might be part of one, broader environmental illness.

\section{INTRODUCTION}

People often experience symptoms such as headaches, fatigue, musculoskeletal pain, sleep problems and bowel disturbances, which are not necessarily related to a medical condition. More than $80 \%$ of the general population experiences at least one of such non-specific physical symptoms (NSPS) in any given month [1] and [2]. When presented to the general practice (GP), between $30 \%$ and $50 \%$ of NSPS cannot be sufficiently explained by a pathological cause and are often labeled as medically unexplained [3] and [4]; according to more recent evidence, these rates can be even higher [5]. However, the term "medically unexplained" is perceived as negative by patients [6] or ambiguous, connoting that the health provider is not able to help or that the symptoms can only be psychiatrically explained [7]. For these reasons and considering that such symptoms are usually reported in different organ systems [8], the term NSPS will be used in the following. In medical care, NSPS are associated with functional impairment similar to that of patients with medical disorders [9], increased illness behavior [10], high levels of psychological distress [11] and [12] and negative symptom perceptions [13] and [14].

Experiencing NSPS is a main characteristic of self-declared sensitivities attributed to low (in relation to established effect thresholds) levels of exposure to environmental agents such as electromagnetic fields (EMF). However, there is no convincing

evidence for a causal dose-response association and a broadly accepted case definition for patients is missing [15], [16], [17], [18], [19], [20], [21] and [22]. Although not well-established, there is the notion that self-reported sensitivity to EMF sources, described by the WHO as idiopathic environmental intolerance attributed to EMF (IEI-EMF) [23] and other diverse environmental sensitivities, such as those to odorous chemicals, food additives and noise, may constitute dimensions of just one condition; a generalized environmental sensitivity which is usually referred to as idiopathic environmental intolerance (IEI) [24], [25], [26] and [27]. This notion is mainly based on evidence that patients tend to be sensitive to more than one environmental sources [28] and [29] and the lack of symptom patterns [28]; IEI has been considered as part of the broader spectrum of functional somatic syndromes [12] and can co-occur with syndromes such as fibromyalgia and chronic fatigue [30]. However, evidence on the clinical pertinence of symptoms reported by environmentally sensitive individuals is still scarce. Important information regarding the clinical profile of the patients such as prevalence of registry-based medical and psychiatric morbidity and prescribed medication is also missing at the population level.

On the one hand, only a diagnostic evaluation could sufficiently determine whether underlying pathology accounts for the symptoms [31] and [32]. On the other hand, persistent presentation of NSPS to the GP is relatively rare [33], [34] and [35] and patients who seek health care are not always those with increased functional impairment [32], [36], [37] and [38]. This means that a large pool of symptomatic cases in the population has not been studied in primary care research [39]. Evidence from studies in the general population and among disaster survivors suggests that 
Baliatsas, C., Kamp, I. van, Hooiveld, M., Yzermans, J., Lebret, E. Comparing non-specific physical symptoms in environmentally sensitive patients: prevalence, duration, functional status and illness behavior. Journal of Psychosomatic Research: 2014, 76(5), 405-413

NSPS reported in surveys share several features with NSPS in medical care, showing that increased number of self-reported NSPS is a strong indicator of functional impairment and illness behavior [2] and [7]. However, it is not clear yet whether this is the case for NSPS reported by individuals with environmental sensitivities, such as IEI-EMF and the broader condition of IEI. Additional components of symptom severity, such as duration, should also be considered to understand the clinical importance of symptomatology [32].

The following research questions were addressed in the present study: 1) Do people with IEI-EMF and those with general environmental sensitivity experience more NSPS and NSPS of longer duration compared to participants without such sensitivities? 2) Do the examined groups differ in terms of symptom patterns, functional status and illness behavior? 3) What is the association between selfreported NSPS and functional impairment, illness behavior and GP-registered NSPS among sensitive and non-sensitive individuals?

\section{METHODS}

\section{Study design and participants}

Data were collected within the framework of an epidemiological study into NSPS in relation to actual and perceived exposure to EMF (EMPHASIS). The study was carried out between January 21 and 23 June 2011 in the Netherlands, combining selfadministered questionnaires and electronic medical records (EMR) of health problems, registered in GPs within the Dutch Information Network of General Practices (LINH) [40]; every Dutch citizen is obliged to be registered at one GP, so the population listed in family practice can be used as the denominator in epidemiological studies [40], [41] and [42]. Data collection within the LINH network is carried out according to the Dutch legislation on privacy. Each patient is coded with an anonymous administrative number. The key to this coding number is only with the general practitioner. The privacy regulation of the study was approved by the Dutch Data Protection Authority. Based on the Law on Medical Scientific Research (WMO), the Dutch Medical Ethics Committee decided that an ethical approval was not required.

Twenty-one practices, varying in terms of number of patients and level of urbanization were selected from the primary care database of the Netherlands Institute for Health Services Research (NIVEL). Registered patients were listed according to postal codes and house number; a geographical information system (GIS) layer of these addresses was then created, resulting to a total pool of 76,684 eligible addresses. A random sample among the adult population ( $\geq 18$ years) was drawn from the GP registry data set, initially stratified by age, gender and preliminary estimates of EMF exposure from mobile phone base stations [43]. Only one adult was sampled from each household. All invitees $(n=13,007)$ received a letter from their GP to fill out a questionnaire, either electronically or in a paper version, entitled "Living environment, technology and health", along with an information leaflet and informed consent form. If a completed questionnaire had not been received, a reminder letter was sent two weeks after the first invitation and a second reminder two weeks later. This resulted in $n=5933$ respondents (response rate: $46 \%$ ). Twenty percent of the respondents filled out the survey online. A non- 
Baliatsas, C., Kamp, I. van, Hooiveld, M., Yzermans, J., Lebret, E. Comparing non-specific physical symptoms in environmentally sensitive patients: prevalence, duration, functional status and illness behavior. Journal of Psychosomatic Research: 2014, 76(5), 405-413

response follow-up on a shorter version of the questionnaire was also conducted, including $n=505$ individuals.

\section{Case definitions}

Selection of individuals with IEI-EMF was based on findings from a recent systematic evaluation of the relevant literature [21], considering that: 1) IEI-EMF is a highly heterogeneous condition in terms of severity and associated EMF sources; 2) self-reported (hyper) sensitivity to EMF is the most often used criterion for patient identification in the literature; 3) most people with IEI-EMF tend to be sensitive to more than one EMF source. Therefore, two items were used to assess IEI-EMF in the study sample, asking the extent to which people agree with the following statements:

1) "I am sensitive to mobile phone base stations and devices related to communication systems (e.g. mobile phones, wireless internet etc.)" and 2) "I am sensitive to electrical devices (e.g. domestic appliances etc.)"; answers were scored on a five-point scale, ranging from "strongly disagree" to "strongly agree". Those who indicated "quite agree" to "strongly agree" were included in the IEI-EMF group. A list of nine items assessing sensitivity to several environmental stressors (other than EMF) such as chemical substances, smells in general and in relation to scented detergents, noise, light, various materials, color, temperature changes and cold or warm environment was used to assess general environmental sensitivity (GES), adapted from Stansfeld et al. [44]. Answers were scored in a similar format as the items on IEI-EMF mentioned above. Respondents with a score at or above the 90th percentile of the score distribution (which corresponds to an average per-item response of at least "quite agree"), were included in the GES group. Participants who had more than one items missing were excluded from subsequent analyses.

\section{Assessment of self-reported non-specific physical symptoms (NSPS)}

To assess NSPS, 23 items from the recently developed Symptoms and Perceptions (SaP) scale [45] were selected. These correspond to physical symptoms similar to those reported by patients in general practice, based on the International Classification of Primary Care (ICPC-1) [46]. The included items ask respondents on a binary scale whether they experienced any of the examined symptoms in the past month; if so, respondents are asked about how long they have been bothered by these symptom(s), with responses formed on a 5-point scale, with "over 6 months" as the highest value. A higher total score in the corresponding characteristics indicates increased number of NSPS and related duration (Internal consistency based on the total analyzed sample: Cronbach's $\alpha=.80$ for and $\alpha=.82$ respectively).

Moreover, the sum scores were added together and categorized into four ranges, based on the approach of van den Berg et al. [7], to present more explicitly the relationship between graded increases in NSPS and the different indicators of functional status and illness behavior: The first range was 0 to 1 symptom, the second 2 to 9 symptoms, the third 10-14 symptoms and the fourth 15 or more symptoms. Following similar methodology, the total score on duration was 
Baliatsas, C., Kamp, I. van, Hooiveld, M., Yzermans, J., Lebret, E. Comparing non-specific physical symptoms in environmentally sensitive patients: prevalence, duration, functional status and illness behavior. Journal of Psychosomatic Research: 2014, 76(5), 405-413

categorized into 4 ranges as well, corresponding to different percentiles ( $>$ 50th, 50th-79th, 80th-94th and 95th), based on the distribution reported by the NS group.

\section{Assessment of GP-registered NSPS}

Non-specific physical symptoms in EMR were registered by the GP according to the ICPC-1 [46]. The evaluation of the clinical judgment of the GP on the symptoms was based on "episodes of care", representing the period from the first presentation of a health problem to a general practice until the completion of the last encounter for the same problem [47]. An episode was defined as "non-specific" if no medical diagnosis had been registered as an explanation for the symptoms, during the year before the completion of the present study. In order to evaluate the association between selfreported and registry based NSPS, we compared the 23 self-reported NSPS with potentially corresponding NSPS in the medical records of the participants [7]. For example, the symptom "headache" corresponded to the ICPC codes N01 (headache) and N02 (tension headache). The total prevalence of registered-NSPS was treated as a dichotomous variable.

Assessment of functional status

For the same period, the GP-registered prevalence of prescriptions related to painkillers, tranquilizers (benzodiazepines) and antidepressants were examined, classified according to the Anatomical Therapeutic Chemical Classification system (ATC) [48].

Participants also completed the General Health subscale of the RAND-36 Health Survey questionnaire [49], which is scored from 0 to 100. A higher score represents better physical functioning.

Sleep quality was assessed using a 10-item version of the Groningen Sleep Quality Scale (GSQS) [50] and [51]. Answers were formatted on a binary scale, with a higher sum score demonstrating lower self-reported sleep quality. Psychological distress was assessed with the 12-item version of the General Health Questionnaire (GHQ-12) [52], [53] and [54]. The 4-point Likert-type scoring method was used in the present analyses; a higher total item score indicates increased distress.

\section{Measures of illness behavior and symptom perceptions}

Participants were asked whether they consulted a GP, a psychologist/psychotherapist and/or an alternative therapist (e.g. homeopathist, acupuncturist or paranormal therapist) and also whether they used any unprescribed medication within the past year.

Symptom perceptions were assessed using the items related to consequences and emotional response of the Brief Illness Perceptions Questionnaire (Brief-IPQ) [55] and [56]. The items were scored on a 10-point Likert scale and referred to the symptom perceived as the most important. Higher scores indicate a greater perceived influence of the reported symptom on life and a stronger, negative emotional response.

Finally, information was obtained on socio-demographic characteristics, lifestyle indicators and GP-registered (based on the ICPC-1) medical (co)morbidity and psychiatric (co)morbidity. 
Baliatsas, C., Kamp, I. van, Hooiveld, M., Yzermans, J., Lebret, E. Comparing non-specific physical symptoms in environmentally sensitive patients: prevalence, duration, functional status and illness behavior. Journal of Psychosomatic Research: 2014, 76(5), 405-413

\section{Data analysis}

To examine potential differences between the three groups in terms of symptom report, functional status, illness behavior and symptom perceptions, linear (for the continuous outcomes) and logistic (for the dichotomous outcomes) regression analyses were used to control for socio-demographic characteristics and medical and psychiatric morbidity. None of the examined continuous scores exceeded the suggested acceptable values for skewness [57]. No risk for multicollinearity was observed. Analysis of variance (one-way ANOVA), the chi-squared test, Cramer's V, and the unpaired samples $t$-test were performed for the descriptive analyses and to examine the associations between symptom categories and indicators of functional status, illness behavior and perceptions. Depending on the type of analyzed variables, effect sizes (regression coefficient, ORs, Cramer's V statistic, Pearson r coefficient) are presented for the main results. The non-parametric equivalent of the ANOVA (Kruskal-Wallis test) was employed to verify the consistency of the findings. To determine whether medical morbidity affected the results, analyses were repeated for participants without registered medical conditions. Post-hoc comparisons were also performed to verify differences between the symptom groups, using the GamesHowell and Bonferroni procedures [58] and [59]. In all tests, the significance level was set at $\mathrm{p}<.05$. When self-reported NSPS were examined as a sum score, respondents who had more than five items on the 23-symptom list missing were excluded from the analyses.

Missing values in the rest of the self-reported measures were treated according to the guidelines or previous publications on these measures. Statistical analyses were carried out using IBM SPSS Statistics (SPSS Inc. version 19, Chicago IL, USA).

\section{RESULTS}

\section{Descriptive analyses and non-response}

Based on the employed case definition criteria and after exclusion of associated incomplete items $(\mathrm{n}=144)$, a total sample of 5789 respondents was available for analysis; $n=202$ (3.5\%) and $n=514$ (8.8\%) met the criteria for the IEI-EMF and GES group respectively, while the rest of the participants $(n=5073)$ formed the " control", non- (environmentally) sensitive (NS) sample.

Seventy-seven (38\%) of participants in the IEI-EMF group also met the criteria for GES. Demographic characteristics, lifestyle indicators and medical and psychiatric morbidity for the three groups are presented in Table 1. Compared to nonrespondents, participants in the total sample were younger (mean age 51.8, SD 17.1 versus 55.0 SD 18.9, $\mathrm{p}=.001$ ), higher educated (higher vocational education or university 32\% vs. 21.5\%, Cramer's V $=.096, \mathrm{p}=.00$ ) and with better perceived health (good, very good or excellent perceived health $82 \%$ vs. $73.5 \%$, OR .6, 95\% CI $.48-.76, \mathrm{p}=.00)$.

\section{[TABLE 1]}

There was no significant difference in gender distribution (female gender $58 \%$ vs. 59.5\%, OR 1.05, 95\% CI .86-1.29, p = .61). Among the non-respondents, 89\% 
Baliatsas, C., Kamp, I. van, Hooiveld, M., Yzermans, J., Lebret, E. Comparing non-specific physical symptoms in environmentally sensitive patients: prevalence, duration, functional status and illness behavior. Journal of Psychosomatic Research: 2014, 76(5), 405-413

provided reasons for not participating in the study: (26\%) stated that they had no time, $22.5 \%$ had no interest to participate, $14.5 \%$ had no health complaints and $26 \%$ provided various other (additional) reasons.

\section{NSPS, functional status and illness behavior: differences between GES, IEI- EMF and controls (NS)}

Controls reported a mean number of 5.0 (SD 3.8) NSPS in the past month, which was significantly lower than the mean number of 6.9 (SD 4.5) symptoms in the IEIEMF group and the mean number of 7.7 (SD 4.5) symptoms in the GES group ( $\mathrm{p}=$ .00 ). The total prevalence of registry-based NSPS was 35\% in the NS group, $42 \%$ in the IEI-EMF and $43 \%$ in the GES group ( $\mathrm{p}=.001)$.

There was a higher prevalence and longer duration of all self-reported symptoms among people with environmental sensitivities, especially those with GES, compared to the NS group (Table 2 and Table 3, Fig. 1); symptoms in particular organ systems such as the digestive and cardiovascular, were strikingly pronounced in the GES and IEI-EMF group respectively.

\section{[TABLE 3] [FIGURE 1]}

Participants in the sensitive groups had higher levels of functional impairment, symptom scores, negative symptom perceptions and illness behavior; the latter was more related to alternative therapies rather than consulting a GP (Table 4).

\section{CSVAssociation between self-reported NSPS and indicators of functional status and illness behavior}

View in workspaceDownload as With increasing number and duration of selfreported NSPS in the three groups, there was an increase in GP-registered NSPS and the examined indicators of functional impairment and illness behavior (Fig. 1, Table 5 and Table 6). Significant associations were verified by post-hoc comparisons (data not shown). In the two environmentally sensitive groups, not all associations reached statistical significance. For instance, although there was a significantly higher prevalence of registered NSPS with increasing number and duration of self-reported NSPS in the NS group (Cramer's $V_{\text {number }}=.17, \mathrm{p}=.00 \& \mathrm{~V}_{\mathrm{dur}}=.21, \mathrm{p}=.00$ ) and with increasing symptom duration in the GES group $\left(\mathrm{V}_{\text {number }}=.12, \mathrm{p}=.07, \mathrm{~V}_{\mathrm{dur}}=\right.$ $.16, \mathrm{p}=.01)$, such associations were not observed for the IEI-EMF group $\left(\mathrm{V}_{\text {number }}=\right.$ $.15, \mathrm{p}=.3, \mathrm{~V}_{\mathrm{dur}}=.17, \mathrm{p}=.2$ ) (Fig. 1). The results of ANOVA did not change after repeating the analyses with non-parametric tests. Overall, the two highest categories of symptom number and duration ( $\geq 10$ and 80th percentile respectively) remained the ones with the highest scores on functional impairment, illness behavior and negative symptom perceptions after exclusion of respondents with medical and psychiatric morbidity (data not shown).

\section{DISCUSSION}

The present study focused on NSPS and potentially clinically relevant characteristics among people with and without self-reported environmental sensitivities. Results showed that the IEI-EMF and GES groups were considerably more symptomatic, with more chronic symptoms, higher levels of functional impairment, negative symptom perceptions and illness behavior that was mainly related to psychological and alternative therapies. Effect sizes for these differences remained moderate to 
Baliatsas, C., Kamp, I. van, Hooiveld, M., Yzermans, J., Lebret, E. Comparing non-specific physical symptoms in environmentally sensitive patients: prevalence, duration, functional status and illness behavior. Journal of Psychosomatic Research: 2014, 76(5), 405-413

strong, even after adjustment for medical and psychiatric morbidity. Moreover, there were no distinct differences in the prevalence of GP consultations compared to controls, which is in line with recent evidence [60]. Collectively, increasing number and duration of self-reported NSPS were strongly associated with decrease in functional status and moderately associated with increase in illness behavior, negative symptom perceptions and prevalence of GP-registered NSPS; associations were robust across groups, as indicated by the consistency of the reported effect sizes. Results are in agreement with evidence from studies on disaster survivors and community samples [2], [7] and [14].

Almost half of the respondents in the NS group with a range between 10 and 14 selfreported NSPS in the past month, had at least one NSPS in their medical records; this was over $60 \%$ for those who experienced 15 or more NSPS. Similar findings were observed for the categories of longer symptom duration. This pattern was less consistent for the GES and IEI-EMF compared to the NS group: The prevalence of registered NSPS dropped at the highest categories of symptom severity, possibly because of the low (given their functional status) rates of medical consultations, while this was not the case for the prevalence of other types of therapies. This might be explained by the fact that the course of idiopathic environmental sensitivities can be chronic, lasting for years [16], [61] and [62]. It is therefore possible that there was an underestimation of the prevalence rates of registered NSPS and/or medication among environmentally sensitive patients because they already consulted their GP for their symptoms and/or follow other types of consultation/therapy.

This is to our knowledge the largest investigation so far on symptom characteristics of people with GES and IEI-EMF in terms of group sizes and health indicator assessment. It is also the first study addressing a wide range of NSPS in terms of both number and duration in combination with GP-registry data of registered NSPS and medication, based on a large primary care database. Although the assessment of self-reported NSPS was based on a recently developed scale, we used it in relation to an extended set of (self-reported and registry based) health indicators, showing a number of associations comparable with studies that used different questionnaires [2], [7] and [63], indicating consistency across various measures. Moreover, the prevalence of registered medical morbidity and anxiety and depressive disorder represents real-life practice and was comparable with 12-month rates from epidemiological studies in the Netherlands and other countries [64], [65], [66], [67], [68] and [69].

In the absence of an established case definition for environmental illnesses [16] and [21], the IEI-EMF and GES group were defined based on a systematic evaluation of the peer-reviewed literature and use of items on several environmental exposures respectively. We used case-definitions that were independent of attributed symptoms, aiming to a more objective investigation of symptom profiles, without predisposing participants through leading questions. The fact that we adjusted for the presence of common medical and psychiatric disorders makes it unlikely that all the betweengroup differences and the increased symptomatology in the sensitive groups are the result of an unrecognized medical condition, although there is often some comorbidity between medical and/or psychiatric conditions and NSPS [70], [71] and [72].

Some limitations of the study should be acknowledged. The first one is related to the sensitivity and specificity of the ICPC codes, which we used to compare GP- 
Baliatsas, C., Kamp, I. van, Hooiveld, M., Yzermans, J., Lebret, E. Comparing non-specific physical symptoms in environmentally sensitive patients: prevalence, duration, functional status and illness behavior. Journal of Psychosomatic Research: 2014, 76(5), 405-413

registered and self-reported NSPS. It is possible that not all symptoms presented by the patients were registered by the GP or the GP used an ICPC code that we did not consider as corresponding to the self-reported symptom; these could lead to an underestimation of the prevalence of people with registered NSPS in the sample

(false negatives). Second, we defined an episode as "non-specific" if it was not related with a medical diagnosis during the year before the completion of data collection for our questionnaire survey. Although this time interval could be considered sufficient for the investigation of such health outcomes, some of the participants might have been diagnosed with a medical condition a few days or months earlier or after the set timeframe. Finally, despite the large sample, some risk for selection bias cannot be ruled out. Since the overall respondents were healthier than the non-respondents, we may have underestimated the prevalence of symptoms to some degree. However, the response rate of the survey is considered satisfactory and comparable to other studies on residential EMF exposure and NSPS [30]. This study aimed to provide insight into clinically relevant characteristics and symptom features of the examined groups. Taking the current findings into account, the notion that IEI-EMF may be part of a broader condition such as GES (or IEI) could be strengthened, considering: 1) the similarities between the sensitive groups in terms of functional impairment and illness behavior 2) the prominence of neurological symptoms, fatigue and muscular pain in both groups and 2) the fact that approximately $40 \%$ of participants with IEI-EMF met the criteria for GES and the rest of this group reported high levels of general sensitivity as well (although lower than the threshold that was used for GES).

While more than $25 \%$ in the GES and IEI-EMF group reported $\geq 10$ NSPS in the past month, the one-year prevalence of diagnosed somatization disorder and/or neurasthenia was $2.3 \%$ and $1.5 \%$ respectively. This might imply that undiagnosed somatoform disorders are more pronounced among people with environmental sensitivities, considering the significant overlap demonstrated in clinical investigations [30] and [74] and that existing diagnostic criteria have been criticized for their restrictiveness [73]. However, this seems to be only a part of the spectrum and can be influenced by the methodology of identifying patients with self-reported sensitivities.

Symptoms can occur due to different interrelated factors, psychological and environmental [75]. In the case of IEI-EMF for instance, on the one hand, a bioelectromagnetic mechanism cannot be ruled out completely, given the methodological challenges that experimental and observational research in this field are confronted with [76]. On the other hand, a strong body of experimental evidence suggests that patients tend to experience symptoms when they believe they are being exposed regardless of whether these beliefs are accurate [19] and [77], highlighting the importance of psychological processes [78] and [79]. We therefore suggest that environmental illnesses should be investigated in line with a psychobiological approach, taking into account the interaction of different potentially causal determinants.

A noteworthy finding was the very high rates of alternative therapy consultations in the sensitive groups, especially IEI-EMF, in agreement with some evidence in the literature [80] and [81]. Solutions might be sought in better communication between patients and physicians. Dealing with medically unexplained conditions is an 
Baliatsas, C., Kamp, I. van, Hooiveld, M., Yzermans, J., Lebret, E. Comparing non-specific physical symptoms in environmentally sensitive patients: prevalence, duration, functional status and illness behavior. Journal of Psychosomatic Research: 2014, 76(5), 405-413

important and challenging task for primary care that requires time and serious consideration of patient's concerns and at the same time prevention of unnecessary interventions [82] and [83]. Medical training does not prepare physicians to deal with symptomatic conditions such as IEI-EMF. As a result, their advice and recommendations are often not evidence-based, leading patients to further insecurity [84]. There is a need for the development and dissemination of a multidisciplinary case-definition protocol, which will constitute a first step towards the identification of environmental sensitivities in primary care and the development of effective treatment strategies.

\section{COMPETING INTEREST STATEMENT}

The authors have no competing interests to report.

\section{ACKNOWLEDGMENTS}

The current study is part of the Dutch project EMPHASIS "Non-specific physical symptoms in relation to actual and perceived exposure to EMF and the underlying mechanisms", funded by The Netherlands Organization for Health Research and Development (ZonMw) (project number: 85100002). The study sponsor had no involvement in the study design, collection, analysis, writing and interpretation of the data and in the decision to submit the study for publication. We gratefully acknowledge the cooperation of respondents and GPs. In addition, we would like to thank Petra ten Veen and Elsbeth Leeuw-Stravers regarding their help on the management of the EMR data and Caroline Ameling for her helpful comments on the paper.

\section{REFERENCES}

[1] K Kroenke, ME Arrington, AD Mangelsdorff The prevalence of symptoms in medical outpatients and the adequacy of therapy Arch Intern Med, 150 (1990), pp. 1685-1689

[2] DAWM van der Windt, ZM Dunn, MN Spies-Dorgelo, CD Mallen, AH Blankestein, WAB Stalman Impact of physical symptoms on perceived health in the community J Psychosom Res, 64 (2008), pp. 265-274

[3] L Kroenke, RK Price Symptoms in the community. Prevalence, classification, and psychiatric comorbidity Arch Intern Med, 153 (1993), pp. 2474-2480

[4] AJ Barsky, JF Borus Functional somatic syndromes Ann Intern Med, 130 (1999), pp. 910-921

[5] S Körber, D Frieser, N Steinbrecher, W Hiller Classification characteristics of the Patient Health Questionnaire-15 for screening somatoform disorders in a primary care setting J Psychosom Res, 71 (2011), pp. 142-147

[6] J Stone, W Wojcik, D Durrance, A Carson, S Lewis, L Mackenzie et al. What should we say to patients with symptoms unexplained by disease? "The number needed to offend" BMJ, 325 (2002), pp. 1449-1450

[7] P Henningsen, P Fink, C Hausteiner-Wiehle, W Rief Terminology, classification and concepts $\mathrm{F}$ Creed, P Henningsen, P Fink (Eds.), Medically unexplained symptoms, somatization and bodily distress: developing better clinical services, Cambridge University Press (2011), pp. 43-68 
Baliatsas, C., Kamp, I. van, Hooiveld, M., Yzermans, J., Lebret, E. Comparing non-specific physical symptoms in environmentally sensitive patients: prevalence, duration, functional status and illness behavior. Journal of Psychosomatic Research: 2014, 76(5), 405-413

[8] B van den Berg, L Grievink, RK Stellato, CJ Yzermans, E Lebret Symptoms and related functioning in a traumatized community Arch Intern Med, 165 (2005), pp. 2402-2407

[9] AL Komaroff, LR Fagioli, TH Doolittle, B Gandek, MA Gleit, RT Guerriero et al. Health status in patients with chronic fatigue syndrome and in general population and disease comparison groups Am J Med, 101 (1996), pp. 281-290

[10] S Hatcher, B Arroll Assessment and management of medically unexplained symptoms BMJ, 336 (2008), pp. 1124-1128

[11] MWM De Waal, IA Arnold, JAH Eekhof, AM van Hemert Somatoform disorders in general practice: prevalence, functional impairment and co-morbidity with anxiety and depressive disorders Br J Psychiatry, 184 (2004), pp. 470-476

[12] S Wessely, C Nimnuan, M Sharpe Functional somatic syndromes: one or many? Lancet, 354 (1999), pp. 936-939

[13] R Moss-Morris, W Wrapson Representational beliefs about functional somatic syndromes. In the self regulation of health and illness behavior LD Cameron, $\mathrm{H}$ Leventhal (Eds.)Routledge, London (2003), pp. 119-137

[14] L Frostholm, E Oernboel, KS Christensen, T Toft, F Olesen, J Weinman et al. Do illness perceptions predict health outcomes in primary care patients? A 2-year follow-up study J

Psychosom Res, 62 (2007), pp. 129-138

[15] M Roosli Radiofrequency electromagnetic field exposure and nonspecific symptoms of ill health: a systematic review Environ Res, 107 (2008), pp. 277-287

[16] M Lacour, T Zunder, K Schmidtke, P Vaith, C Scheidt Multiple chemical sensitivity syndrome (MCS) - suggestions for an extension of the US MCS-case definition Int J Hyg Environ Health, 208 (2005), pp. 141-151

[17] J Das-Munshi, GJ Rubin, S Wessely Multiple chemical sensitivities: a systematic review of provocation studies J Allergy Clin Immunol, 118 (2006), pp. 1257-1264

[18] GJ Rubin, R Nieto-Hernandez, S Wessely Idiopathic environmental intolerance attributed to electromagnetic fields (formerly 'electromagnetic hypersensitivity'): an updated systematic review of provocation studies Bioelectromagnetics, 31 (2010), pp. 1-11

[19] M Röösli, P Frei, E Mohler, K Hug Systematic review on the health effects of exposure to radiofrequency electromagnetic fields from mobile phone base stations Bull World Health Organ, 88 (2010), pp. 887-896

[20] C Augner, T Gnambs, R Winker, A Barth Acute effects of electromagnetic fields emitted by GSM mobile phones on subjective well-being and physiological reactions: a metaanalysis Sci Total Environ, 424 (2012), pp. 11-15

[21] C Baliatsas, I van Kamp, E Lebret, GJ Rubin Idiopathic environmental intolerance attributed to electromagnetic fields (IEI-EMF): a systematic review of identifying criteria BMC Public Health, 12 (2012), p. 643

[22] C Baliatsas, I van Kamp, J Bolte, M Schipper, J Yzermans, E Lebret Non-specific physical symptoms and electromagnetic field exposure in the general population: can we get more specific? A systematic review Environ Int, 41 (2012), pp. 15-28

[23] WHO Fact sheet no. 296: electromagnetic fields and public health World Health Organization (2005) [http://www.emfandhealth.com/WHO_EMSensitivity.pdf]

[24] R Kreutzer Idiopathic environmental intolerance: case definition issues Occup Med, 15 (2000), pp. 511-517

[25] S Bornschein, H Förstl, T Zilker Idiopathic environmental intolerances (formerly multiple chemical sensitivity) psychiatric perspectives J Intern Med, 250 (2001), pp. 309-321 
Baliatsas, C., Kamp, I. van, Hooiveld, M., Yzermans, J., Lebret, E. Comparing non-specific physical symptoms in environmentally sensitive patients: prevalence, duration, functional status and illness behavior. Journal of Psychosomatic Research: 2014, 76(5), 405-413

[26] MJ Andersson, L Andersson, M Bende, E Millqvist, S Nordin The idiopathic environmental intolerance symptom inventory: development, evaluation, and application J Occup Environ Med, 51 (2009), pp. 838-847

[27] J Bailer, M Witthöft, C Paul, C Bayerl, F Rist Evidence for overlap between idiopathic environmental intolerance and somatoform disorders Psychosom Med, 67 (2005), pp. 921929

[28] P Henningsen, S Priebe New environmental illnesses: what are their characteristics? Psychother Psychosom, 72 (2003), pp. 231-234

[29] L Hillert, N Berglind, BB Arnetz, T Bellander Prevalence of self-reported hypersensitivity to electric or magnetic fields in a population-based questionnaire survey Scand J Work Environ Health, 28 (2002), pp. 33-41

[30] LA Aaron, D Buchwald A review of the evidence for overlap among unexplained clinical conditions Ann Intern Med, 134 (2001), pp. 868-881

[31] CS North Somatization in survivors of catastrophic trauma: a methodological review Environ Health Perspect, 110 (2002), pp. 637-640

[32] B van den Berg Physical symptoms that are frequently unexplained among survivors of the Enschede fireworks disaster Utrecht University, Doctoral Dissertation (2007)

[33] LA Green, GE Fryer, BP Yawn, D Lanier, SM Dovey The ecology of medical care revisited N Engl J Med, 344 (2001), pp. 2021-2025

[34] B van den Berg, CJ Yzermans, PG van der Velden, RK Stellato, E Lebret, L Grievink

Are physical symptoms among survivors of a disaster presented to the general practitioner?A comparison between self-reports and GP data BMC Health Serv Res, 7 (2007), p. 150

[35] PFM Verhaak, SA Meijer, AP Visser, G Wolters Persistent presentation of medically unexplained symptoms in general practice Fam Pract, 23 (2006), pp. 414-420

[36] AJ Barsky Hidden reasons some patients visit doctors Ann Intern Med, 94 (1981), pp. 492-498

[37] JL Jackson, K Kroenke The effect of unmet expectations among adults presenting with physical symptoms Ann Intern Med, 134 (2001), pp. 889-897

[38] NA Koloski, NJ Talley, PM Boyce Predictors of health care seeking for irritable bowel syndrome and nonulcer dyspepsia: a critical review of the literature on symptom and psychosocial factors Am J Gastroenterol, 96 (2001), pp. 1340-1349

[39] LM Verbrugge, FJ Ascione Exploring the iceberg. Common symptoms and how people care for them Med Care, 25 (1987), pp. 539-569

[40] I Stirbu-Wagner, SA Dorsman, S Visscher, R Davids, JV Gravestein, H Abrahamse et al. The Netherlands information network of general practice. Facts and numbers in primary care [in Dutch]. Utrecht/Nijmegen: NIVEL/IQ (2010) [http://www.linh.nl]

[41] J van der Lei, JS Duisterhout, HP Westerhof, E van der Does, PVM Cromme, WM Boon et al. The introduction of computer-based patient records in the Netherlands Ann Intern Med, 19 (1993), pp. 1036-1041

[42] M Hooiveld, T van de Groep, TJM Verheij, MAB van der Sande, RA Verheij, MAJB Tacken et al. Prescription of antiviral drugs during the 2009 influenza pandemic: an observational study using electronic medical files of general practitioners in the Netherlands BMC Pharmacol Toxicol, 14 (2013), p. 55

[43] HP Neitzke, J Osterhoff, K Peklo, H Voigt Determination of exposure due to mobile phone base stations in an epidemiological study Radiat Prot Dosimetry, 124 (2007), pp. 35-39

[44] SA Stansfeld, CR Clark, LM Jenkins, A Tarnopolsky Sensitivity to noise in a community sample: measurement of psychiatry disorder and personality Psychol Med, 15 (1985), pp. 243-254 
Baliatsas, C., Kamp, I. van, Hooiveld, M., Yzermans, J., Lebret, E. Comparing non-specific physical symptoms in environmentally sensitive patients: prevalence, duration, functional status and illness behavior. Journal of Psychosomatic Research: 2014, 76(5), 405-413

[45] J Yzermans, C Baliatsas, I Van Kamp Symptoms and perceptions scale (SaP): an exploratory psychometric analysis [abstract] Psychol Health, 27 (2012), pp. s1-s354

[46] H Lamberts, M Wood International classification of primary care Oxford University Press, Oxford (1987)

[47] WONCA Classification committee An international glossary for general/family practice Fam Pract, 12 (1995), pp. 341-369

[48] WHO Guidelines for ATC classification and DDD assignment WHO Collaborating Centre for Drug Statistics Methodology, Oslo (2003)

[49] KI Van der Zee, R Sanderman Measuring general health with the RAND-36: a manual: Dutch version Groningen, The Netherlands, Noordelijk Centrum voor Gezondheidsvraagstukken (1993)

[50] TF Meijman, AHG de Vries-Griever, G de Vries, R Kampman The construction and evaluation of a one-dimensional scale measuring subjective sleep quality Heijmans BulletinState University Groningen, The Netherlands (1985)

[51] TF Meijman Over vermoeidheid: Arbeidspsychologische studies naar de beleving van belastingseffecten [In Dutch] University of Amsterdam, Doctoral Dissertation (1991)

[52] DP Goldberg The detection of psychiatric illness by questionnaire. Maudsley monograph no. 21 Oxford University Press, Oxford (1973)

[53] MWJ Koeter, J Ormel General Health Questionnaire, Nederlandse bewerking handleiding [General Health Questionnaire, Dutch version manual] Swets \& Zeitlinger, Lisse (1991)

[54] N Hoeymans, A Garssen, $G$ Westert, $P$ Verhaak Measuring mental health of the Dutch population: a comparison of the GHQ-12 and the MHI-5 Health Qual Life Outcomes, 2 (2004), pp. 23-29

[55] AA Kaptein, IM van Korlaar, M Scharloo IPQ-K (2004) [http://www.uibno/ipq/pdf/B-IPQDutch.pdf]

[56] E Broadbent, KJ Petrie, J Main, J Weinman The brief illness perception questionnaire J Psychosom Res, 60 (2006), pp. 631-637

[57] Cameron A Kurtosis Encyclopedia of social science research methods M Lewis-Beck, A Bryman, T Liao (Eds.)SAGE Publications, Thousand Oaks CA (2004), pp. 544-545 [Inc. http://dx.doi.org.proxy.library.uu.nl/10.4135/9781412950589.n467]

[58] PA Games, HJ Keselman, JC Rogan Simultaneous pairwise multiple comparison procedures for means when sample sizes are unequal Psychol Bull, 90 (1981), pp. 594598

[59] RG Miller Simultaneous statistical inference Springer-Verlag, New York (1981)

[60] DA Katerndahl, IR Bell, RF Palmer, CS Miller Chemical intolerance in primary care settings: prevalence, comorbidity, and outcomes Ann Fam Med, 10 (2012), pp. 357-365

[61] L Hillert, B Kolmodin Hedman, BF Dölling, BB Arnetz Cognitive behavioral therapy for patients with electric sensitivity - a multidisciplinary approach in a controlled study

Psychother Psychosom, 67 (1998), pp. 302-310

[62] B Andersson, M Berg, BB Arnetz, L Melin, I Langlet, SA Lidén Cognitive-behavioral treatment of patients suffering from "electric hypersensitivity". Subjective effects and reactions in a double-blind provocation study J Occup Environ Med, 38 (1996), pp. 752758

[63] K Kroenke, RL Spitzer, JBW Williams The PHQ-15: validity of a new measure for evaluating the severity of somatic symptoms Psychosom Med, 64 (2002), pp. 258-266

[64] RV Bijl, A Ravelli, G van Zessen Prevalence of psychiatric disorder in the general population: results of the Netherlands Mental Health Survey and Incidence Survey

(NEMESIS) Soc Psychiatry Psychiatr Epidemiol, 33 (1998), pp. 587-595 
Baliatsas, C., Kamp, I. van, Hooiveld, M., Yzermans, J., Lebret, E. Comparing non-specific physical symptoms in environmentally sensitive patients: prevalence, duration, functional status and illness behavior. Journal of Psychosomatic Research: 2014, 76(5), 405-413

[65] RC Kessler, WT Chiu, O Demler, KR Merikangas, EE Walters Prevalence, severity, and comorbidity of 12-month DSM-IV disorders in the National Comorbidity Survey Replication Arch Gen Psychiatry, 62 (2005), pp. 617-627

[66] HU Wittchen, F Jacobi Size and burden of mental disorders in Europe - a critical review and appraisal of 27 studies Eur Neuropsychopharmacol, 15 (2005), pp. 357-376 [67] J Maas, RA Verheij, S de Vries, P Spreeuwenberg, FG Schellevis, PP Groenewegen Morbidity is related to a green living environment J Epidemiol Community Health, 63 (2009), pp. 967-973

[68] Lucassen $P$ van Boven, $H$ van Ravesteijn, Hartman TO, H Bor, E van WeelBaumgarten et al. Do unexplained symptoms predict anxiety or depression? Ten-year data from a practice-based research network $\mathrm{Br} J$ Gen Pract (2011), pp. e316-e325

[69] R Johansson, P Carlbring, A Heedman, B Paxling, G Andersson Depression, anxiety and their comorbidity in the Swedish general population: point prevalence and the effect on health-related quality of life Peer J, 1 (2013), p. e98 http://dx.doi.org.proxy.library.uu.nl/10.7717/peerj.98

[70] AJ Barsky, EJ Orav, DW Bates Somatization increases medical utilization and costs independent of psychiatric and medical comorbidity Arch Gen Psychiatry, 62 (2005), pp. 903-910

[71] RC Smith, FC Dwamena Classification and diagnosis of patients with medically unexplained symptoms J Gen Intern Med, 5 (2007), pp. 685-691

[72] M Feuerstein, GL Bruns, C Pollman, BL Todd Management of unexplained symptoms in survivors of cancer J Oncol Pract, 6 (2010), pp. 308-311

[73] K Voigt, A Nagel, B Meyer, G Langs, C Braukhaus, B Löwe

Towards positive diagnostic criteria: a systematic review of somatoform disorder diagnoses and suggestions for future classification J Psychosom Res (2010), pp. 403-414

[74] J Bailer, M Witthöft, F Rist Psychological predictors of short- and medium term outcome in individuals with idiopathic environmental intolerance (IEI) and individuals with somatoform disorders J Toxicol Environ Health, 71 (2008), pp. 766-775

[75] A Spurgeon Models of unexplained symptoms associated with occupational and environmental exposures Environ Health Perspect, 110 (2002), pp. 601-605

[76] C Baliatsas, GJ Rubin Electromagnetic fields, symptoms and idiopathic environmental intolerance M Röösli (Ed.), Epidemiology of electromagnetic fields, CRC press (2014), pp. 261-274

[77] R Szemerszky, F Koteles, R Lihi, G Bardos Polluted places or polluted minds? An experimental sham-exposure study on background psychological factors of symptom formation in 'idioptahic environmental intolerance' attributed to electromagnetic fields Int J Hyg Environ Health, 213 (2010), pp. 387-394

[78] F Köteles, R Szemerszky, M Gubányi, J Körmendi, CS Szekrényesi, R Lloyd et al. Idiopathic environmental intolerance attributed to electromagnetic fields (IEI-EMF) and electrosensibility (ES)—are they connected? Int J Hyg Environ Health, 216 (2013), pp. 362-370

[79] M Witthöft, GJ Rubin Are media warnings about the adverse health effects of modern life self-fulfilling? An experimental study on idiopathic environmental intolerance attributed to electromagnetic fields (IEI-EMF) J Psychosom Res, 74 (2013), pp. 206-212

[80] A Huss, M Röösli Consultations in primary care for symptoms attributed to electromagnetic fields - a survey among general practitioners BMC Public Health, 6 (2006), p. 267

[81] B Stenberg, J Bergdahl, B Edvardsson, N Eriksson, G Lindén, L Widman Medical and social prognosis for patients with perceived hyprsensitivity to electricity and skin symptoms 
Baliatsas, C., Kamp, I. van, Hooiveld, M., Yzermans, J., Lebret, E. Comparing non-specific physical symptoms in environmentally sensitive patients: prevalence, duration, functional status and illness behavior. Journal of Psychosomatic Research: 2014, 76(5), 405-413

related to the use of visual display terminals Scand J Work Environ Health, 5 (2002), pp.

349-357

[82] AJE Dirkzwager, PFM Verhaak Patients with persistent medically unexplained symptoms in general practice: characteristics and quality of care BMC Fam Pract, 8 (2007), p. 33

[83] TO Hartman, LJ Hassink-Franke, PL Lucassen, KP van Spaendonck, C van Weel Explanation and relations. How do general practitioners deal with patients with persistent medically unexplained symptoms: a focus group study BMC Fam Pract, 10 (2009), p. 68 [84] G Berg-Beckhoff, K Heyer, B Kowall, J Breckenkamp, O Razum The views of primary care physicians on health risks from electromagnetic fields Dtsch Arztebl Int, 107 (2010), pp. 817-823

\section{TABLES}

Table 1. : Basic demographic characteristics, morbidity and lifestyle indicators of the three investigated groups (valid cases)

\begin{tabular}{|c|c|c|c|}
\hline & $\begin{array}{l}\text { NS group (n } \\
=5073)\end{array}$ & $\begin{array}{l}\text { GES group } \\
(n=514)\end{array}$ & $\begin{array}{l}\text { IEI-EMF } \\
\operatorname{group}(\mathbf{n}=\mathbf{2 0 2})\end{array}$ \\
\hline \multicolumn{4}{|l|}{ Demographic characteristics } \\
\hline \multicolumn{4}{|l|}{ Age (\%) } \\
\hline $18-24$ & 6.4 & $3.3^{\mathrm{a}}$ & 3.0 \\
\hline $25-44$ & 32.2 & $23.0^{\mathrm{a}}$ & $20.8^{\mathrm{b}}$ \\
\hline $45-64$ & 39.8 & 42.8 & 39.6 \\
\hline $65-74$ & 12.3 & $16.1^{\mathrm{a}}$ & 14.8 \\
\hline $75+$ & 9.3 & $14.8^{\text {and }}$ & $21.8^{\text {and }}$ \\
\hline Mean age (SD) & $51.0(17.0)$ & $56.5(16.5)^{\mathrm{a}}$ & $58.5(17.7)^{\mathrm{b}}$ \\
\hline Female gender (\%) & 56.0 & $78.0^{\text {and }}$ & $61.4^{\mathrm{C}}$ \\
\hline \multicolumn{4}{|l|}{ Education (\%) ${ }^{\mathrm{d}}$} \\
\hline Lower & 22.4 & $27.0^{\mathrm{a}}$ & $34.2^{b}$ \\
\hline Middle & 44.8 & 45.2 & 41.3 \\
\hline Higher & 32.8 & $27.8^{\mathrm{a}}$ & $24.5^{b}$ \\
\hline \multicolumn{4}{|l|}{ Marital status (\%) } \\
\hline Unmarried & 20.2 & 19.0 & 23.6 \\
\hline Married, living together & 64.8 & $60.0^{\mathrm{a}}$ & $57.8^{\mathrm{b}}$ \\
\hline Divorced & 7.0 & $12.4^{\mathrm{a}}$ & 7.5 \\
\hline Widowed & 8.0 & 8.6 & 11.1 \\
\hline \multicolumn{4}{|l|}{ Occupational status (\%) } \\
\hline $\begin{array}{l}\text { Employed, school, } \\
\text { housewife/man }\end{array}$ & 73.5 & $62.5^{\mathrm{a}}$ & $62.9^{\mathrm{b}}$ \\
\hline Unemployed, incapacitated & 7.8 & $13.0^{\mathrm{a}}$ & 10.4 \\
\hline Retired & 18.7 & $24.5^{\mathrm{a}}$ & $26.7^{\mathrm{b}}$ \\
\hline Born in the Netherlands (\%) & 93.8 & $89.8^{\mathrm{a}}$ & $84.4^{b}$ \\
\hline
\end{tabular}


Baliatsas, C., Kamp, I. van, Hooiveld, M., Yzermans, J., Lebret, E. Comparing non-specific physical symptoms in environmentally sensitive patients: prevalence, duration, functional status and illness behavior. Journal of Psychosomatic Research: 2014, 76(5), 405-413

\begin{tabular}{|l|l|l|l|}
\hline & $\begin{array}{l}\text { NS group (n } \\
=\mathbf{5 0 7 3})\end{array}$ & $\begin{array}{l}\text { GES group } \\
(\mathbf{n}=\mathbf{5 1 4})\end{array}$ & $\begin{array}{l}\text { IEI-EMF } \\
\text { group (n = 202) }\end{array}$ \\
\hline $\begin{array}{l}\text { Medical morbidity (registered) } \\
\text { \%) }\end{array}$ & & & \\
\hline Asthma & 3.5 & $5.4^{\mathrm{a}}$ & 4.5 \\
\hline Acute myocardial infarction & .9 & .4 & $2.5^{\text {and }}$ \\
\hline $\begin{array}{l}\text { Chronic obstructive pulmonary } \\
\text { disease (COPD) }\end{array}$ & 2.6 & $4.7^{\mathrm{a}}$ & 3.0 \\
\hline Diabetes & 5.7 & $8.4^{\mathrm{a}}$ & 8.9 \\
\hline Duodenal/peptic ulcers & .2 & .0 & .6 \\
\hline Hypertension (uncomplicated) & 12.0 & $15.4^{\mathrm{a}}$ & 14.9 \\
\hline Rheumatoid arthritis & .6 & 1.2 & .5 \\
\hline Herpes zoster & .5 & $1.4^{\mathrm{a}}$ & .5 \\
\hline Psoriasis & .9 & .6 & $2.5^{\text {and }}$ \\
\hline Cancer (malignant neoplasm) & 2.6 & $5.1^{\mathrm{a}}$ & 3.5 \\
\hline $\begin{array}{l}\text { Psychiatric morbidity } \\
\text { (registered) (\%) }\end{array}$ & & & \\
\hline Anxiety disorder & 1.0 & $3.1^{\mathrm{a}}$ & 1.0 \\
\hline Depressive disorder & 2.3 & $4.5^{\mathrm{a}}$ & 3.0 \\
\hline Lifestyle indicators & & & 34.5 \\
\hline $\begin{array}{l}\text { Mean BMI (body mass index) } \\
\text { (SD) }\end{array}$ & $25.4(4.8)$ & $25.4(5.1)$ & $26.0(4.6)$ \\
\hline Smoking (\%) & & 3.0 & 2.3 \\
\hline No, never & 36.8 & 40.5 & \\
\hline No, in the past & 20.5 & $16.2^{\mathrm{a}}$ & 19.0 \\
\hline Yes & 1.8 & 3.0 & 26.5 \\
\hline $\begin{array}{l}\text { Alcohol and/or substance abuse } \\
\text { > 6 months (\%) }\end{array}$ & & & \\
\hline
\end{tabular}

Note: Significance level set at $\mathrm{p}<.05$.

A Significant difference between GES \& NS group.

${ }^{B}$ Significant difference between IEI-EMF \& NS group.

C Significant difference between GES \& IEI-EMF group.

${ }^{D}$ Lower: No education or primary school or lower secondary education; Middle: Intermediate vocational or intermediate general secondary or higher general secondary education; Higher: Higher vocational or university education. 
Baliatsas, C., Kamp, I. van, Hooiveld, M., Yzermans, J., Lebret, E. Comparing non-specific physical symptoms in environmentally sensitive patients: prevalence, duration, functional status and illness behavior. Journal of Psychosomatic Research: 2014, 76(5), 405-413

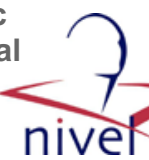

Table 2. Prevalence of 23 self-reported NSPS in the NS, GES \& IEI-EMF group and between-group differences ${ }^{\mathrm{a}}$

\begin{tabular}{|c|c|c|c|c|c|c|}
\hline Self-reported NSPS & $\begin{array}{l}\text { Corresponding } \\
\text { ICPC code(s) }\end{array}$ & & & & & \\
\hline & & $\mathbf{N S}^{\mathbf{b}}$ & GES $^{\mathbf{c}}$ & $\begin{array}{l}\text { OR (95\% } \\
\text { CI) }\end{array}$ & $\begin{array}{l}\text { IEI- } \\
\text { EMF }\end{array}$ & $\begin{array}{l}\text { OR }(95 \% \\
\text { CI })\end{array}$ \\
\hline Fatigue/tiredness & A04 & 52.4 & 68.5 & $\begin{array}{l}1.8(1.5- \\
2.3)^{*}\end{array}$ & 62.2 & $\begin{array}{l}1.5(1.1- \\
2.1)^{\top}\end{array}$ \\
\hline Abdominal/stomach pain & D01-D02, D06 & 22.8 & 39.9 & $\begin{array}{l}2.0(1.6- \\
2.5)^{*}\end{array}$ & 30.2 & $\begin{array}{l}1.5(1.1- \\
2.2)^{\top}\end{array}$ \\
\hline Nausea & D09 & 11.2 & 20.8 & $\begin{array}{l}1.8(1.4- \\
2.4)^{*}\end{array}$ & 15.3 & $1.4(.9-2.3)$ \\
\hline Diarrhea or constipation & D11-D12 & 20.4 & 31.5 & $\begin{array}{l}1.7(1.3- \\
2.1)^{*}\end{array}$ & 23.0 & $1.1(.8-1.7)$ \\
\hline Eye symptoms & F01-F02 & 17.8 & 31.4 & $\begin{array}{l}1.8(1.4- \\
2.3)^{*}\end{array}$ & 23.8 & $1.3(.9-1.9)$ \\
\hline Ear symptoms & H01-H03, H13 & 12.7 & 21.3 & $\begin{array}{l}1.6(1.2- \\
2.1)^{*}\end{array}$ & 20.9 & $\begin{array}{l}1.6(1.0- \\
2.3)^{\top}\end{array}$ \\
\hline $\begin{array}{l}\text { Heart } \\
\text { palpitations/awareness }\end{array}$ & K04 & 12.6 & 21.7 & $\begin{array}{l}1.5(1.2- \\
1.9)^{\ddagger}\end{array}$ & 26.3 & $\begin{array}{l}2.3(1.6- \\
3.4)^{*}\end{array}$ \\
\hline Neck or shoulder symptoms & L01, L08 & 37.0 & 54.3 & $\begin{array}{l}1.7(1.4- \\
2.1)^{*}\end{array}$ & 47.2 & $\begin{array}{l}1.4(1.0- \\
2.0)^{\top}\end{array}$ \\
\hline Back pain & L02-L03 & 34.9 & 49.2 & $\begin{array}{l}1.6(1.3- \\
2.0)^{*}\end{array}$ & 42.7 & $1.3(.9-1.8)$ \\
\hline $\begin{array}{l}\text { Pain/pressure in chest and } \\
\text { heart region }\end{array}$ & L04, K01-K03 & 8.6 & 16.4 & $\begin{array}{l}1.9(1.4- \\
2.5)^{*}\end{array}$ & 20.0 & $\begin{array}{l}2.5(1.6- \\
3.8)^{*}\end{array}$ \\
\hline $\begin{array}{l}\text { Arm/elbow/hand/wrist } \\
\text { symptoms }\end{array}$ & L09-L12 & 23.7 & 37.3 & $\begin{array}{l}1.5(1.2- \\
1.9)^{*}\end{array}$ & 27.8 & $.9(.6-1.4)$ \\
\hline $\begin{array}{l}\text { Leg/hip/knee/foot } \\
\text { symptoms }\end{array}$ & L13-L15, L17 & 31.6 & 46.3 & $\begin{array}{l}1.4(1.2- \\
1.8)^{*}\end{array}$ & 42.4 & $1.2(.8-1.7)$ \\
\hline Pain in muscles & L18 & 30.3 & 41.2 & $\begin{array}{l}1.5(1.2- \\
1.9)^{*}\end{array}$ & 38.5 & $\begin{array}{l}1.5(1.0- \\
2.1)^{\top}\end{array}$ \\
\hline Headache & N01-N02 & 36.8 & 51.0 & $\begin{array}{l}1.8(1.5- \\
2.2)^{*}\end{array}$ & 43.6 & $\begin{array}{l}1.7(1.2- \\
2.5)^{\ddagger}\end{array}$ \\
\hline Tingling of fingers, feet or & N05 & 15.7 & 27.0 & $1.6(1.3-$ & 25.0 & $1.6(1.1-$ \\
\hline
\end{tabular}


Baliatsas, C., Kamp, I. van, Hooiveld, M., Yzermans, J., Lebret, E. Comparing non-specific physical symptoms in environmentally sensitive patients: prevalence, duration, functional status and illness behavior. Journal of Psychosomatic Research: 2014, 76(5), 405-413

\begin{tabular}{|c|c|c|c|c|c|c|}
\hline Self-reported NSPS & $\begin{array}{l}\text { Corresponding } \\
\text { ICPC code(s) }\end{array}$ & & & & & \\
\hline & & $\mathbf{N S}^{\mathbf{b}}$ & $\mathbf{G E S}^{\mathbf{c}}$ & $\begin{array}{l}\text { OR (95\% } \\
\text { CI) }\end{array}$ & $\begin{array}{l}\text { IEI- } \\
\text { EMF }\end{array}$ & $\begin{array}{l}\text { OR }(95 \% \\
\text { CI) }\end{array}$ \\
\hline toes & & & & $2.0)^{*}$ & & $2.3)^{\top}$ \\
\hline $\begin{array}{l}\text { Dizziness or feeling light- } \\
\text { headed }\end{array}$ & N17 & 19.4 & 37.4 & $\begin{array}{l}2.0(1.6- \\
2.5)^{*}\end{array}$ & 36.5 & $\begin{array}{l}2.3(1.7- \\
3.3)^{*}\end{array}$ \\
\hline Sleep problems & P06 & 25.6 & 42.7 & $\begin{array}{l}1.7(1.4- \\
2.1)^{*}\end{array}$ & 44.4 & $\begin{array}{l}2.2(1.5- \\
3.0)^{*}\end{array}$ \\
\hline $\begin{array}{l}\text { Memory or concentration } \\
\text { problems }\end{array}$ & P20 & 19.8 & 36.2 & $\begin{array}{l}2.0(1.6- \\
2.4)^{*}\end{array}$ & 35.0 & $\begin{array}{l}1.9(1.4- \\
2.8)^{*}\end{array}$ \\
\hline Shortness of breath & R02-R04, R29 & 7.8 & 17.0 & $\begin{array}{l}2.0(1.5- \\
2.6)^{*}\end{array}$ & 16.3 & $\begin{array}{l}1.9(1.2- \\
3.0)^{\neq}\end{array}$ \\
\hline Cough & R05 & 21.9 & 27.2 & $\mid \begin{array}{l}1.2(.99- \\
1.5)\end{array}$ & 27.8 & $\begin{array}{l}1.4(1.0- \\
2.1)^{\top}\end{array}$ \\
\hline Nasal symptoms & R07 & 24.5 & 37.8 & $\begin{array}{l}1.8(1.5- \\
2.2)^{*}\end{array}$ & 26.0 & $1.1(.8-1.6)$ \\
\hline Skin symptoms & S01, S06-S07 & 21.8 & 38.2 & $\begin{array}{l}2.1(1.7- \\
2.6)^{*}\end{array}$ & 35.6 & $\begin{array}{l}1.9(1.4- \\
2.7)^{*}\end{array}$ \\
\hline Weight change & T07-T08 & 11.6 & 16.9 & $\begin{array}{l}1.3(.99- \\
1.7)^{* *}\end{array}$ & 18.5 & $\begin{array}{l}1.7(1.1- \\
2.6)^{\top}\end{array}$ \\
\hline
\end{tabular}

Note: $\mathrm{Tp}^{\mathrm{p}}<.05 ; \neq \mathrm{p}<.01 ;{ }^{*} \mathrm{p}<.001 ; * * \mathrm{p}=.05$.

Abbreviations: OR, Odds ratio; CI, Confidence interval.

${ }^{A}$ Between-group differences were adjusted for age, gender, education, ethnic background, medical morbidity, psychiatric morbidity.

${ }^{\mathrm{B}}$ Reference group.

${ }^{\mathrm{C}}$ No significant differences between GES \& IEI-EMF group.

Table 3. Prevalence of self-reported NSPS with duration of $\geq 4$ months in the NS, GES \& IEI-EMF group and between-group differences ${ }^{a}$

\begin{tabular}{|l|l|l|l|l|l|}
\hline Self-reported NSPS & & & & & \\
\hline & NS $^{\mathbf{b}}$ & GES $^{\mathbf{c}}$ & OR (95\% CI) & IEI-EMF & OR (95\% CI) \\
\hline Fatigue/tiredness & 23.3 & 42.5 & $2.0(1.6-2.5) *$ & 34.6 & $1.6(1.1-2.3)^{\ddagger}$ \\
\hline Abdominal/stomach pain & 8.7 & 20.9 & $2.4(1.8-3.1) *$ & 14.0 & $1.5(.9-2.4)$ \\
\hline Nausea & 2.2 & 8.2 & $2.7(1.8-4.1) *$ & 3.4 & $1.1(.4-2.8)$ \\
\hline Diarrhea or constipation & 6.2 & 14.1 & $2.0(1.5-2.7) *$ & 10.1 & $1.4(.8-2.5)$ \\
\hline
\end{tabular}


Baliatsas, C., Kamp, I. van, Hooiveld, M., Yzermans, J., Lebret, E. Comparing non-specific physical symptoms in environmentally sensitive patients: prevalence, duration, functional status and illness behavior. Journal of Psychosomatic Research: 2014, 76(5), 405-413

\begin{tabular}{|c|c|c|c|c|c|}
\hline \multirow[t]{2}{*}{ Self-reported NSPS } & \multirow[b]{2}{*}{$\mathrm{NS}^{\mathbf{b}}$} & \multirow[b]{2}{*}{ GES $^{\mathbf{C}}$} & \multirow[b]{2}{*}{ OR (95\% CI) } & \multirow[b]{2}{*}{ IEI-EMF } & \multirow[b]{2}{*}{ OR (95\% CI) } \\
\hline & & & & & \\
\hline Eye symptoms & 6.4 & 14.6 & $2.0(1.5-2.8)^{*}$ & 10.7 & $1.3(.7-2.2)$ \\
\hline Ear symptoms & 6.4 & 11.6 & $1.6(1.1-2.2)^{\ddagger}$ & 13.2 & $1.7(1.0-2.8)^{\top}$ \\
\hline $\begin{array}{l}\text { Heart } \\
\text { palpitations/awareness }\end{array}$ & 5.6 & 11.2 & $1.6(1.2-2.3)^{\ddagger}$ & 15.1 & $2.8(1.8-4.5)^{*}$ \\
\hline $\begin{array}{l}\text { Neck or shoulder } \\
\text { symptoms }\end{array}$ & 19.3 & 34.0 & $1.7(1.4-2.2)^{*}$ & 24.0 & $1.1(.7-1.6)$ \\
\hline Back pain & 18.3 & 32.1 & $1.7(1.4-2.2) *$ & 25.4 & $1.3(.9-1.9)$ \\
\hline $\begin{array}{l}\text { Pain/pressure in chest and } \\
\text { heart region }\end{array}$ & 3.4 & 8.8 & $2.4(1.6-3.5)^{*}$ & 8.3 & $2.4(1.3-4.5)^{\ddagger}$ \\
\hline $\begin{array}{l}\text { Arm/elbow/hand/wrist } \\
\text { symptoms }\end{array}$ & 13.7 & 25.5 & $1.6(1.2-2.0)^{*}$ & 17.6 & $1.0(.6-1.6)$ \\
\hline $\begin{array}{l}\text { Leg/hip/knee/foot } \\
\text { symptoms }\end{array}$ & 19.5 & 32.8 & $1.5(1.2-1.8)^{\ddagger}$ & 26.6 & $1.0(.7-1.5)$ \\
\hline Pain in muscles & 8.5 & 18.4 & $1.9(1.4-2.5)^{*}$ & 19.4 & $2.0(1.3-3.0)^{\ddagger}$ \\
\hline Headache & 10.2 & 24.5 & $2.6(2.0-3.3)^{*}$ & 16.6 & $2.0(1.3-3.0)^{\ddagger}$ \\
\hline $\begin{array}{l}\text { Tingling of fingers, feet } \\
\text { or toes }\end{array}$ & 8.6 & 16.7 & $1.7(1.2-2.2) *$ & 12.7 & $1.3(.8-2.1)$ \\
\hline $\begin{array}{l}\text { Dizziness or feeling } \\
\text { light-headed }\end{array}$ & 7.2 & 19.1 & $2.4(1.8-3.2)^{*}$ & 16.0 & $2.2(1.4-3.5)^{*}$ \\
\hline Sleep problems & 14.6 & 29.9 & $1.9(1.5-2.4)^{*}$ & 28.2 & $2.1(1.4-3.0)^{*}$ \\
\hline $\begin{array}{l}\text { Memory or concentration } \\
\text { problems }\end{array}$ & 11.4 & 26.3 & $2.3(1.8-2.9)^{*}$ & 20.7 & $1.8(1.2-2.8)^{\ddagger}$ \\
\hline Shortness of breath & 4.1 & 10.1 & $2.3(1.6-3.2)^{*}$ & 7.5 & $1.6(.8-3.0)$ \\
\hline Cough & 5.3 & 8.0 & $1.3(.9-2.0)$ & 11.8 & $2.1(1.2-3.5)^{\ddagger}$ \\
\hline Nasal symptoms & 10.3 & 19.7 & $2.0(1.5-2.6)^{*}$ & 12.6 & $1.1(.7-1.9)$ \\
\hline Skin symptoms & 11.7 & 25.7 & $2.4(1.9-3.0)^{*}$ & 18.0 & $1.4(.9-2.2)$ \\
\hline Weight change & 6.4 & 11.6 & $1.6(1.2-2.2)^{\ddagger}$ & 9.4 & $1.4(.8-2.5)$ \\
\hline
\end{tabular}

Note: $\mathrm{Tp}<.05 ; \neq \mathrm{p}<.01 ;{ }^{*} \mathrm{p}<.001 ; * * \mathrm{p}=.05$.

Abbreviations: OR, Odds ratio; CI, Confidence interval.

${ }^{A}$ Between-group differences were adjusted for age, gender, education, ethnic background, medical morbidity, psychiatric morbidity.

${ }^{\mathrm{B}}$ Reference group.

${ }^{\mathrm{C}}$ Significant differences between GES \& IEI-EMF (ref) group: abdominal/stomach pain (OR 1.7, 95\% CI 1.0-3.0, p<.05), nausea (OR 2.7, 95\% CI 1.0-7.4, $\mathrm{p}<.05$ ), neck or shoulder symptoms (OR 1.6, 95\% CI 1.0-2.4, $\mathrm{p}<.05$ ), nasal symptoms (OR 1.8, 95\% CI 1.1-3.2, $\mathrm{p}<.05)$. 
Baliatsas, C., Kamp, I. van, Hooiveld, M., Yzermans, J., Lebret, E. Comparing non-specific physical symptoms in environmentally sensitive patients: prevalence, duration, functional status and illness behavior. Journal of Psychosomatic Research: 2014, 76(5), 405-413

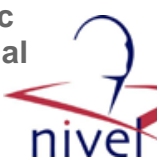

Table 4. Unadjusted and adjusted differences between groups on determinants of functional status, illness behavior, symptom perceptions \& symptom scores

\begin{tabular}{|c|c|c|c|c|c|c|}
\hline & \multicolumn{2}{|l|}{ GES vs. NS ${ }^{\mathrm{a}}$} & \multicolumn{2}{|c|}{ IEI-EMF vs. NS ${ }^{\mathrm{a}}$} & \multicolumn{2}{|c|}{ GES vs. IEI-EMF ${ }^{\mathrm{a}}$} \\
\hline & Unadjusted & Adjusted $^{\mathrm{b}}$ & Unadjusted & Adjusted $^{\mathrm{b}}$ & Unadjusted & Adjusted $^{\mathrm{b}}$ \\
\hline \multicolumn{7}{|c|}{ Regression coefficient (95\% CI) } \\
\hline General health & $\mid \begin{array}{l}-9.1(-11.0 \\
\text { to }-7.4)^{*}\end{array}$ & $\begin{array}{l}-7.4(-9.0 \\
\text { to }-5.7)^{*}\end{array}$ & $\begin{array}{l}-6.6(-9.3 \\
\text { to }-3.9)^{*}\end{array}$ & $\begin{array}{l}-3.9(-6.5 \text { to }- \\
1.2)^{\neq}\end{array}$ & $\begin{array}{l}-2.5(-6.1 \\
\text { to } 1.0)\end{array}$ & $\begin{array}{l}-3.1(- \\
6.7 \text { to } .5)\end{array}$ \\
\hline Sleep quality & $.9(.7 \text { to } 1.2)^{*}$ & $6(.4 \text { to } .9)^{*}$ & $\begin{array}{l}1.0(.6 \text { to } \\
1.4)^{*}\end{array}$ & $.9(.5 \text { to } 1.3)^{*}$ & $\begin{array}{l}-.07(-.6 \\
\text { to } .4)\end{array}$ & $\begin{array}{l}-.2(-.8 \\
\text { to } .3)\end{array}$ \\
\hline \begin{tabular}{|l} 
Psychological \\
distress
\end{tabular} & \begin{tabular}{|l|}
$1.3(.8$ to \\
$1.8)^{*}$
\end{tabular} & $\begin{array}{l}1.0(.5 \text { to } \\
1.5)^{*}\end{array}$ & $.9(.2 \text { to } 1.7)^{\top}$ & $1.0(.2 \text { to } 1.8)^{\ddagger}$ & $\begin{array}{l}.3(-.6 \text { to } \\
1.4)\end{array}$ & $\begin{array}{l}.04(-1.0 \\
\text { to } 1.1)\end{array}$ \\
\hline Perceived impact ${ }^{c}$ & $1.2(.9$ to 1.4$)$ & $\begin{array}{l}1.0(0.7 \text { to } \\
1.2)^{*}\end{array}$ & $.6(.2 \text { to } 1.1)^{\ddagger}$ & $.5(.09 \text { to } 1.0)^{\ddagger}$ & $\begin{array}{l}.5(.02 \text { to } \\
1.0)^{\top}\end{array}$ & $\begin{array}{l}.4(-.05 \text { to } \\
1.0)\end{array}$ \\
\hline $\begin{array}{l}\text { Emotional response } \\
\mathrm{c}\end{array}$ & $\begin{array}{l}1.5(1.2 \text { to } \\
1.8)^{*}\end{array}$ & $\begin{array}{l}1.3(1.0 \text { to } \\
1.6)^{*}\end{array}$ & $.8(.3 \text { to } 1.3)^{\ddagger}$ & $.8(.3 \text { to } 1.4)^{\ddagger}$ & $\begin{array}{l}.7(.1 \text { to } 1.2) \\
T\end{array}$ & $\begin{array}{l}.6(-.01 \\
\text { to1.2)** }\end{array}$ \\
\hline $\begin{array}{l}\text { Number of self- } \\
\text { reported NSPS }\end{array}$ & $\begin{array}{l}2.6(2.3 \text { to } \\
3.0)^{*}\end{array}$ & $\begin{array}{l}2.1(1.8 \text { to } \\
2.5)^{*}\end{array}$ & $\begin{array}{l}1.8(1.2 \text { to } \\
2.4)^{*}\end{array}$ & $1.7(1.1 \text { to } 2.3)^{*}$ & $\begin{array}{l}.8(.03 \text { to } \\
1.6)^{\top}\end{array}$ & $\begin{array}{l}.5(-.3 \text { to } \\
1.3)\end{array}$ \\
\hline $\begin{array}{l}\text { Duration of self- } \\
\text { reported NSPS }\end{array}$ & $\begin{array}{l}9.0(7.8 \text { to } \\
10.1)^{*}\end{array}$ & $\begin{array}{l}7.2(6.1 \text { to } \\
8.4)^{*}\end{array}$ & $\begin{array}{l}5.7 \text { (3.8 to } \\
7.5)^{*}\end{array}$ & 5.0 (3.0 to 6.8$)^{*}$ & $\begin{array}{l}3.3(.4 \text { to } \\
6.2)^{\top}\end{array}$ & $\begin{array}{l}2.7(-.3 \text { to } \\
5.7)\end{array}$ \\
\hline \multicolumn{7}{|l|}{ OR $(95 \%$ CI) } \\
\hline Consulting a GP & $1.7(1.3-2.2)^{*}$ & $\mid \begin{array}{l}1.2(.98- \\
1.6)\end{array}$ & $1.2(.8-1.7)$ & $1.0(.7-1.5)$ & $1.4(.96-2.1)$ & $1.2(.8-1.9)$ \\
\hline $\begin{array}{l}\text { Consulting a } \\
\text { psychologist }\end{array}$ & $1.9(1.5-2.4)^{*}$ & $\mid \begin{array}{l}1.9(1.5- \\
2.5)^{*}\end{array}$ & $1.5(1.0-2.3)$ & $2.0(1.3-3.1)^{\ddagger}$ & $1.2(.8-2.0)$ & $1.0(.6-1.6)$ \\
\hline $\begin{array}{l}\text { Consulting an } \\
\text { alternative therapist }\end{array}$ & $2.1(1.6-2.7)^{*}$ & $\begin{array}{l}1.9(1.4- \\
2.5)^{*}\end{array}$ & $\begin{array}{l}3.0(2.0- \\
4.4)^{*}\end{array}$ & $3.8(2.5-5.7)^{*}$ & $.7(.4-1.0)$ & $.5(.3-.8)^{\ddagger}$ \\
\hline $\begin{array}{l}\text { Unprescribed } \\
\text { medication }\end{array}$ & $1.3(1.1-1.6)^{\ddagger}$ & $\mid \begin{array}{l}1.3(1.1- \\
1.6)^{\neq}\end{array}$ & $1.0(.7-1.3)$ & $1.1(.8-1.6)$ & $1.3(.97-1.9)$ & $1.2(.8-1.8)$ \\
\hline Registered NSPS & $1.3(1.1-1.6)^{\ddagger}$ & $1.1(.9-1.4)$ & $1.3(.99-1.7)$ & $1.0(.7-1.4)$ & $1.0(.7-1.4)$ & $1.1(.7-1.6)$ \\
\hline $\begin{array}{l}\text { Prescribed } \\
\text { painkillers }\end{array}$ & $1.4(1.1-1.7)^{\ddagger}$ & $\mid \begin{array}{l}1.2(.97- \\
1.5)\end{array}$ & $1.4(1.0-2.0)$ & $1.2(.9-1.8)$ & $1.0(.7-1.4)$ & $.9(.6-1.4)$ \\
\hline $\begin{array}{l}\text { Prescribed } \\
\text { benzodiazepines }\end{array}$ & $2.1(1.6-2.7)^{*}$ & $\mid \begin{array}{l}1.4(1.0- \\
1.8)^{\top}\end{array}$ & $1.9(1.3-2.8)$ & $1.5(1.0-2.4)^{* *}$ & $1.1(.7-1.7)$ & $1.0(.6-1.6)$ \\
\hline
\end{tabular}


Baliatsas, C., Kamp, I. van, Hooiveld, M., Yzermans, J., Lebret, E. Comparing non-specific physical symptoms in environmentally sensitive patients: prevalence, duration, functional status and illness behavior. Journal of Psychosomatic Research: 2014, 76(5), 405-413

\begin{tabular}{|l|l|l|l|l|l|l|}
\hline & \multicolumn{2}{|l|}{ GES vs. NS $^{\mathrm{a}}$} & \multicolumn{2}{l|}{ IEI-EMF vs. NS ${ }^{\mathrm{a}}$} & \multicolumn{2}{l|}{ GES vs. IEI-EMF $^{\mathrm{a}}$} \\
\hline & Unadjusted & Adjusted $^{\mathrm{b}}$ & Unadjusted $^{\text {Adjusted }}{ }^{\mathrm{b}}$ & \multicolumn{2}{l|}{ Unadjusted $^{\text {Adjusted }^{\mathrm{b}}}$} \\
\hline $\begin{array}{l}\text { Prescribed } \\
\text { antidepressants }\end{array}$ & $2.2(1.7-2.9)^{*}$ & $\begin{array}{l}1.5(1.1- \\
2.1)^{\top}\end{array}$ & $1.5(.95-2.4)$ & $1.3(.7-2.3)$ & $1.5(.9-2.4)$ & $1.1(.6-2.0)$ \\
\hline
\end{tabular}

Note: $\mathrm{Tp}<.05 ; \neq \mathrm{p}<.01 ;{ }^{*} \mathrm{p}<.001 ; * * \mathrm{p}=.05$.

Abbreviations: OR, Odds ratio; CI, Confidence interval.

A Reference group.

B Between-group differences were adjusted for age, gender, education, ethnic background, medical (co)morbidity, psychiatric (co)morbidity.

C Referring to the most important symptom among the ones reported.

Table 6. Association between number and duration of self-reported NSPS and prevalence of illness behavior \& symptom perceptions in the three examined groups十

\begin{tabular}{|c|c|c|c|c|c|c|c|c|}
\hline \multirow[b]{2}{*}{$\begin{array}{l}\text { Illness behavior \& } \\
\text { symptom perceptions }\end{array}$} & \multicolumn{4}{|c|}{ Number of symptoms } & \multicolumn{4}{|c|}{ Duration of symptoms } \\
\hline & $0-1$ & $2-9$ & $10-14$ & $\geq 15$ & $\begin{array}{l}<50 \text { th } \\
\text { percentile }\end{array}$ & $\begin{array}{l}\text { 50th- } \\
\text { 79th } \\
\text { percentile }\end{array}$ & $\begin{array}{l}\text { 80th- } \\
94 \text { th } \\
\text { percentile }\end{array}$ & $\begin{array}{l}\text { 95th } \\
\text { percentile }\end{array}$ \\
\hline \multicolumn{9}{|l|}{ Consulting a GP } \\
\hline $\begin{array}{l}\mathrm{NS}^{\text {and }}\left(\mathrm{V}_{\text {number }}=.22,\right. \\
\left.\mathrm{V}_{\text {dur. }}=.23\right)^{\mathrm{C}}\end{array}$ & 55.0 & 74.7 & 88.7 & 91.5 & 62.8 & 79.4 & 86.6 & 89.3 \\
\hline $\begin{array}{l}\mathrm{GES}^{\text {and }}\left(\mathrm{V}_{\text {number }}=.15\right. \\
\left.\mathrm{V}_{\text {dur. }}=.21\right)^{\mathrm{C}}\end{array}$ & 74.1 & 78.4 & 90.4 & 90.0 & 71.8 & 77.6 & 90.4 & 90.6 \\
\hline $\begin{array}{l}\text { IEI-EMF }{ }^{\mathrm{b}}\left(\mathrm{OR}_{\text {number }}=\right. \\
\left.1.38, \mathrm{~V}_{\text {dur. }}=.23\right)^{\mathrm{c}} \\
\end{array}$ & \multicolumn{2}{|l|}{$76.0^{\neq}$} & \multicolumn{2}{|l|}{$81.4^{\ddagger}$} & 64.5 & 81.6 & 84.6 & 88.0 \\
\hline \multicolumn{9}{|c|}{ Consulting a psychologist } \\
\hline $\begin{array}{l}\mathrm{NS}^{\text {and }}\left(\mathrm{V}_{\text {number }}=.19,\right. \\
\left.\mathrm{V}_{\text {dur. }}=.18\right)^{\mathrm{c}} \\
\end{array}$ & 4.5 & 9.1 & 21.8 & 33.3 & 5.6 & 11.3 & 16.4 & 27.0 \\
\hline $\begin{array}{l}\mathrm{GES}^{\text {and }}\left(\mathrm{V}_{\text {number }}=.18\right. \\
\left.\mathrm{V}_{\text {dur. }}=.2\right)^{\mathrm{C}}\end{array}$ & 3.8 & 14.4 & 27.8 & 24.4 & 7.8 & 15.8 & 22.6 & 29.4 \\
\hline $\begin{array}{l}\text { IEI-EMF }{ }^{\text {and }}\left(\mathrm{OR}_{\text {number }}=\right. \\
\left.4.2, \mathrm{~V}_{\text {dur. }}=.33\right) \\
\end{array}$ & \multicolumn{2}{|l|}{$9.7^{\neq}$} & \multicolumn{2}{|l|}{$31.0^{\ddagger}$} & 6.8 & 5.4 & 23.1 & 37.5 \\
\hline \multicolumn{9}{|c|}{ Consulting an alternative therapist } \\
\hline $\begin{array}{l}\mathrm{NS}^{\text {and }}\left(\mathrm{V}_{\text {number }}=.1, \mathrm{~V}_{\text {dur. }}\right. \\
=.14)^{\mathrm{c}}\end{array}$ & 3.7 & 7.6 & 12.7 & 16.5 & 4.3 & 9.3 & 13.0 & 14.5 \\
\hline $\begin{array}{l}\mathrm{GES}^{\text {and }}\left(\mathrm{V}_{\text {number }}=.15,\right. \\
\left.\mathrm{V}_{\text {dur. }}=.15\right)^{\mathrm{c}}\end{array}$ & 3.8 & 12.9 & 20.9 & 26.8 & 8.7 & 12.9 & 23.3 & 16.5 \\
\hline $\begin{array}{l}\text { IEI-EMF }\left(\mathrm{OR}_{\text {number }}=\right. \\
\left.1.99, \mathrm{~V}_{\text {dur. }}=.16\right)^{\mathrm{C}}\end{array}$ & \multicolumn{2}{|l|}{$17.9^{\neq}$} & \multicolumn{2}{|l|}{$30.2^{\neq}$} & 15.5 & 26.3 & 17.9 & 33.3 \\
\hline
\end{tabular}


Baliatsas, C., Kamp, I. van, Hooiveld, M., Yzermans, J., Lebret, E. Comparing non-specific physical symptoms in environmentally sensitive patients: prevalence, duration, functional status and illness behavior. Journal of Psychosomatic Research: 2014, 76(5), 405-413

\begin{tabular}{|c|c|c|c|c|c|c|c|c|}
\hline \multirow{2}{*}{\begin{tabular}{|l|} 
\\
Illness behavior \& \\
symptom perceptions
\end{tabular}} & \multicolumn{4}{|c|}{ Number of symptoms } & \multicolumn{4}{|c|}{ Duration of symptoms } \\
\hline & $0-1$ & $2-9$ & $10-14$ & $4 \geq 15$ & $\begin{array}{l}<50 \text { th } \\
\text { percentile }\end{array}$ & $\begin{array}{l}\text { 50th- } \\
\text { 79th } \\
\text { percentile }\end{array}$ & $\begin{array}{l}\text { 80th- } \\
94 \text { th } \\
\text { percentile }\end{array}$ & $\begin{array}{l}95 \text { th } \\
\text { percentile }\end{array}$ \\
\hline $\begin{array}{l}\mathrm{NS}^{\text {and }}\left(\mathrm{V}_{\text {number }}=.22,\right. \\
\left.\mathrm{V}_{\text {dur. }}=.16\right)^{\mathrm{C}}\end{array}$ & 27.4 & 53.7 & 61.6 & 66.9 & 41.9 & 57.5 & 58.4 & 62.4 \\
\hline $\begin{array}{l}\text { GES }\left(V_{\text {number }}=.05, V_{\text {dur. }}\right. \\
=.08)^{\mathrm{C}}\end{array}$ & 50.0 & 57.6 & 60.2 & 60.0 & 52.3 & 58.1 & 62.7 & 61.2 \\
\hline $\begin{array}{l}\text { IEI-EMF }{ }^{\mathrm{a}}\left(\mathrm{V}_{\text {number }}=.23 \text {, }\right. \\
\left.\mathrm{V}_{\text {dur. }}=.17\right)^{\mathrm{c}}\end{array}$ & 26.7 & 50.0 & 68.8 & 36.4 & 41.1 & 52.8 & 62.2 & 58.3 \\
\hline \multicolumn{9}{|l|}{ Consequences ${ }^{\dagger}$} \\
\hline $\begin{array}{l}\text { NS }^{\text {and }}\left(r_{\text {number }}=.36, r_{\text {dur. }}\right. \\
=.42)^{\mathrm{c}}\end{array}$ & $\begin{array}{l}4.3 \\
(2.7)\end{array}$ & $\begin{array}{l}5.3 \\
(2.6)\end{array}$ & $\begin{array}{l}7.1 \\
(2.1)\end{array}$ & $\begin{array}{l}7.9 \\
(1.7)\end{array}$ & $4.4(2.6)$ & $5.6(2.4)$ & $6.7(2.2)$ & $8.0(1.8)$ \\
\hline $\begin{array}{l}\mathrm{GES}^{\text {and }}\left(\mathrm{r}_{\text {number }}=.39 \text {, }\right. \\
\left.\mathrm{r}_{\text {dur. }}=.44\right)^{\mathrm{c}}\end{array}$ & $\begin{array}{l}5.0 \\
(3.1)\end{array}$ & $\begin{array}{l}6.2 \\
(2.5)\end{array}$ & $\begin{array}{l}7.6 \\
(1.9)\end{array}$ & $\begin{array}{l}8.0 \\
(2.0)\end{array}$ & $5.0(2.6)$ & $6.2(2.4)$ & $7.1(2.1)$ & $8.2(1.6)$ \\
\hline $\begin{array}{l}\text { IEI-EMF }{ }^{\text {and }}\left(\mathrm{r}_{\text {number }}=\right. \\
\left..36, \mathrm{r}_{\text {dur. }}=.47\right)^{\mathrm{c}}\end{array}$ & $\begin{array}{l}6.7 \\
(.9) \\
\end{array}$ & $\begin{array}{l}5.7 \\
(2.6) \\
\end{array}$ & \begin{tabular}{|l|}
7.6 \\
$(2.1)$ \\
\end{tabular} & \begin{tabular}{|l}
7.5 \\
$(2.6)$ \\
\end{tabular} & $5.4(2.5)$ & $4.9(2.6)$ & $7.2(1.8)$ & $8.2(1.7)$ \\
\hline \multicolumn{9}{|l|}{ Emotional response ${ }^{\dagger}$} \\
\hline $\begin{array}{l}\mathrm{NS}^{\text {and }}\left(\mathrm{r}_{\text {number }}=.36, \mathrm{r}_{\mathrm{dur}} \text {. }\right. \\
=.37)^{\mathrm{c}}\end{array}$ & $\begin{array}{l}2.8 \\
(2.9)\end{array}$ & $\begin{array}{l}4.0 \\
(2.9) \\
\end{array}$ & $\begin{array}{l}6.0 \\
(2.7)\end{array}$ & $\begin{array}{l}7.0 \\
(2.4)\end{array}$ & $3.1(2.8)$ & $4.2(2.9)$ & $5.6(2.8)$ & $6.7(2.7)$ \\
\hline $\begin{array}{l}\mathrm{GES}^{\text {and }}\left(\mathrm{r}_{\text {number }}=.33 \text {, }\right. \\
\left.\mathrm{r}_{\text {dur. }}=.37\right)^{\mathrm{c}}\end{array}$ & $\begin{array}{l}5.5 \\
(2.1)\end{array}$ & $\begin{array}{l}5.3 \\
(2.8)\end{array}$ & $\begin{array}{l}6.1 \\
(2.9)\end{array}$ & $\begin{array}{l}7.8 \\
(2.2)\end{array}$ & $4.3(2.8)$ & $5.2(2.7)$ & $6.2(2.7)$ & $7.3(2.6)$ \\
\hline $\begin{array}{l}\text { IEI-EMF }^{\text {and }}\left(\mathrm{r}_{\text {number }}=\right. \\
\left..32, \mathrm{r}_{\text {dur. }}=.37\right)^{\mathrm{c}}\end{array}$ & $\begin{array}{l}5.0 \\
(3.8)\end{array}$ & $\begin{array}{l}4.7 \\
(3.0)\end{array}$ & $\begin{array}{l}6.2 \\
(2.7)\end{array}$ & $\begin{array}{l}8.0 \\
(1.8)\end{array}$ & $4.3(3.0)$ & $4.6(3.0)$ & $5.6(3.1)$ & $7.4(2.2)$ \\
\hline
\end{tabular}

†Data per symptom category are given as percentage of participants, except for "Perceived impact" \& "Emotional response" which are given as mean scores and their standard deviations (SD). Note: Significance level set at $\mathrm{p}<.05$.

fIEI-EMF group: When the expected count in the chi-squared test was $<5$ in more than one cell (symptom category), the symptom number \& duration scores were dichotomized (cut-off point: $\leq 10$ symptoms $\& \leq 80$ th percentile respectively). $\dagger$ Referring to the most important symptom among the ones reported. ${ }^{\text {A }}$ Significant difference between symptom number categories across rows. ${ }^{B}$ Significant difference between symptom duration categories across rows. ${ }^{\mathrm{C}}$ Effect sizes representing the strength of associations between indicators of illness behavior and symptom perceptions and symptom number and duration for each group; for the associations with the continuous indicators the original symptom sum scores were used (abbreviations: r, Pearson r coefficient; V, Cramer's V; OR, Odds ratio). 